\title{
Evaluation of antimicrobial activity and antibiotic susceptibility profiles of Lactobacillus delbrueckii subsp. bulgaricus and Streptococcus thermophilus strains isolated from commercial yoghurt starter cultures
}

\author{
Oktay YERLIKAYA ${ }^{1 *} \mathbb{D}$, Derya SAYGILI ${ }^{2}$ D, Asli AKPINAR ${ }^{3}$
}

\begin{abstract}
This research investigated the antimicrobial activity and antibiotic susceptibilities of nine Lactobacillus delbrueckii subsp. bulgaricus strains and nine Streptococcus thermophilus strains isolated from commercial yoghurt cultures. The antimicrobial activities of overnight culture strains against Bacillus cereus CECT 131, Bacillus subtilis ATCC 6633, Campylobacter jejuni NCTC 11351, Candida albicans ATCC 14053, Enterobacter aerogenes ATCC 13048, Escherichia coli ATCC 25922, Listeria monocytogenes ATCC 7644, Pseudomonas aeruginosa ATCC 9027, Salmonella typhimurium ATCC 14028 and Staphylococcus aureus ATCC 12600 were investigated using the disc diffusion method. The antibiotic resistance/susceptibility profiles of the strains were determined using antibiotic discs, which included ampicillin $(10 \mu \mathrm{g})$, ampicillin $(25 \mu \mathrm{g})$, bacitracin $(10 \mu \mathrm{g})$, clindamycin $(2 \mu \mathrm{g})$, clindamycin $(10 \mu \mathrm{g})$, erythromycin $(10 \mu \mathrm{g})$, erythromycin $(15 \mu \mathrm{g})$, gentamicin $(10 \mu \mathrm{g})$, gentamicin $(120 \mu \mathrm{g})$, nalidixic acid $(30 \mu)$, neomycin $(10 \mu \mathrm{g})$, novobiocin $(5 \mu \mathrm{g})$, oxacillin $(1 \mu \mathrm{g})$, penicillin (10units), streptomycin $(25 \mu \mathrm{g})$, streptomycin $(300 \mu \mathrm{g})$, tetracycline $(30 \mu \mathrm{g})$ and vancomycin $(30 \mu \mathrm{g})$. The results of the study showed that while the Streptococcus thermophilus strain SY8, Lactobacillus bulgaricus strains LY6, LY8, LY9 and LY10 showed antimicrobial activity for all test microorganisms, Streptococcus thermophilus SY5 strains showed the weakest antimicrobial effect. All the Lactobacillus bulgaricus and Streptococcus thermophilus strains were resistant to oxacillin $(1 \mu \mathrm{g})$ and nalidixic acid $(30 \mu \mathrm{g})$. Indeed, the highest antibiotic susceptibility was seen with antibiotics such as ampicillin $(25 \mu \mathrm{g})$, clindamycin $(10 \mu \mathrm{g})$ and erythromycin $(15 \mu \mathrm{g})$.
\end{abstract}

Keywords: yoghurt bacteria; antimicrobial activity; antibiotic susceptibility; antibiotic resistance; starter cultures.

Practical Applications: This research investigated the antimicrobial activity and antibiotic susceptibilities of nine Lactobacillus delbrueckii subsp. bulgaricus strains and nine Streptococcus thermophilus strains isolated from commercial yoghurt cultures. The study is important in terms of updating our information about the antibiotic resistance and antimicrobial activities of the strains in the combination of commercially produced and marketed yoghurt culture. It is key factor to know the mentioned criteria of the types and strains used in the traditional yoghurt production.

\section{Introduction}

Lactic acid bacteria (LAB) are industrially important microorganisms and are used in various forms in industrial food fermentations. LAB are generally found in milk and dairy products, in plants and human and animal intestinal mucosa. Lactic acid bacteria used in conventional fermented foods are gram-positive, facultative anaerobes, catalase negative, immobilized, lacking cytochromes and are non-spore forming (Carr et al., 2002; Mathur \& Singh, 2005). Nowadays, LAB are reported to cover 17 genera: Aerococcus, Alloiococcus, Dolosigranulum, Enterococcus, Globicatella, Carnobacterium, Lactobacillus, Lactococcus, Leuconostoc, Melissococcus, Lactosphaera, Oenococcus, Pediococcus, Tetragenococcus, Vagococcus, Streptococcus and Weisella (Crowley et al., 2013).

These bacteria, which show heterotrophic feeding patterns, can be found in coccus (spherical), rod (elongated) and oval shapes and tetrad formations and oval shapes and tetrad formation. Bacteria grow at temperatures between 10 to $45^{\circ} \mathrm{C}$,

in high salt concentrations and they can tolerate acid or alkaline conditions (Ranasinghe \& Perera, 2016). LAB found in milk and milk products catabolize glucose in two ways: homofermentative and heterofermentative (Kandler, 1983).

1. Homofermentative LAB: Glucose components via EMP pathways (Embden Meyerhof Parnas) producing 90\% lactic acid and $10 \% \mathrm{CO}_{2}$.

2. Heterofermentative LAB: Glucose components via HMP (Hexose monophosphate) producing lactic acid, ethanol, acetaldehyde, diacetyl, exopolysaccharide and $\mathrm{CO}_{2}$.

LAB help dairy products (cheese, yoghurt, butter, kefyr, koumis etc.) to gain their own aroma, smell and structure (Caplice \& Fitzgerald, 1999). Many bacteria are used as starter cultures for the industrial processing of fermented dairy products. Also, non-starter lactic acid bacteria can originate from the raw

Received 03 Feb., 2020

Accepted: 05 Mar., 2020

${ }^{1}$ Department of Dairy Technology, Faculty of Agriculture, Ege University, Bornova-Izmir, Turkey

${ }^{2}$ Izmir Kavram Vocational School, Culinary Programe, Konak-Izmir, Turkey

${ }^{3}$ Food Engineering Department, Engineering Faculty, Manisa Celal Bayar University, Muradiye Campus, Muradiye-Manisa, Turkey

*Corresponding author: oktay.yerlikaya@ege.edu.tr 
material and the environment. Another important domain for the use of LAB is as a probiotic starter culture (Hill \& Ross, 1998; Cruz et al., 2010; Bintsis, 2018). Probiotic lactic acid bacterial strains are preferred based on their ability to maintain viability within the gastrointestinal tract and to colonize the intestinal tract. One of the most important characteristic of probiotics is as protection against pathogens in the intestinal tract of the host. In addition to all of these, probiotics can also be widely used in many fields like pharmaceuticals in pharmacology (Granato et al., 2010; Ranadheera et al., 2019).

Yoghurt and other fermented milks are trend in market. This is due to the benefits these foods bring to human health (Chetachukwu et al., 2019; Ribeiro et al., 2019). Yoghurt is a probiotic fermented dairy product and have highly digestible proteins. Among fermented dairy product, the most important fermented food is yoghurt. Therefore, yoghurt bacteria are very important to human nutrition. In addition, having antimicrobial activity increases the importance of yoghurt bacteria (Suskovic et al., 2010; Celik et al., 2016, Coskun \& Karabulut Dirican, 2019).

There is a synbiotic relationship between Streptococcus thermophilus and Lactobacillus bulgaricus in yoghurt starter cultures (Liu, 2018). This symbiotic relationship occurs during proteolysis. The level of some amino acids in milk is not enough to develop Streptococcus thermophilus. This deficiency is eliminated by Lactobacillus bulgaricus. When Streptococcus thermophilus develops a certain amount of acidity, Lactobacillus bulgaricus starts to develop and $\beta$-casein hydrolyzes to peptides. However, Lactobacillus bulgaricus also has limited peptidase activity. At this stage, Streptococcus thermophilus becomes active, producing peptidase activity for itself and Lactobacillus bulgaricus (Liu et al., 2012).

Although Streptococcus thermophilus and Lactobacillus bulgaricus are important species in the yoghurt industry, they are in a category of bacteria which most needs to be investigated. The reason for this is the fact that many beneficial effects have been reported, and the mechanism of action has not been identified, leaving many aspects that need to be researched. The main purpose of this research was to investigate the antimicrobial activity and antibiotic susceptibility of some Lactobacillus delbrueckii subsp. bulgaricus and Streptococcus thermophilus strains isolated from commercial yoghurt starter cultures.

\section{Materials and methods}

\subsection{Materials}

Commercial yoghurt cultures were activated, yoghurt was produced in reconstituted skimmed milk containing $12 \%$ non-fat dry matter (Oxoid Skim Milk Powder, Basingstoke, UK). Ten grams of the yoghurt samples were weighed out into stomacher bags. Than mixed with $90 \mathrm{~mL}$ sterile peptone water (Merck, Darmstad, Germany) and homogenized using a Colworth Stomacher 400 (Seward Laboratory, West Sussex, UK). The appropriate dilutions inoculated onto de Man, Rogosa and Sharpe (MRS) Agar (Merck, Darmstad, Germany) and M 17 Agar (Merck, Darmstad, Germany) according to Terzaghi \& Sandine (1975). The M 17 agar plates were incubated at $37^{\circ} \mathrm{C}$ for 48 hours, and the MRS Agar plates were incubated at $42{ }^{\circ} \mathrm{C}$ for 72 hours, anaerobically. To produce the anaerobic environment, an Aerogen agent (Oxoid, Basingstoke, UK) was placed into the anaerobic jars (De Man et al., 1960; Terzaghi \& Sandine, 1975). The morphologically appropriate growing colonies were transferred to Elliker Broth (Difco, Fluka, France) and incubated under appropriate conditions, which were $42{ }^{\circ} \mathrm{C}$ for Lactobacillus bulgaricus and $37^{\circ} \mathrm{C}$ for Streptococcus thermophilus ( 37 to $42^{\circ} \mathrm{C}$ ). After incubation in Lactobacilli Broth and purified by a single colony matching technique, the purity controls of the developing isolates were observed under a light microscope by simple staining with methylene blue. The strains of Lactobacillus bulgaricus were called LY, and the Streptococcus thermophilus strains were called SY.

\subsection{Methods}

\subsubsection{Antimicrobial activity}

Test microorganisms were inoculated into Tryptic Soy Broth (Oxoid, Basingstoke, UK) and incubated under appropriate incubation conditions until the concentration reached from $10^{7}$ to $10^{8} \mathrm{cfu} / \mathrm{ml}$. The optical densities (OD value) of the indicator bacteria were also standardized by adjusting the spectrophotometer (Analytik Jena, Germany) to $0.6 \pm 0.2$ at $600 \mathrm{~nm}$. Overnight cultures of the Lactobacillus bulgaricus and Streptococcus thermophilus strains were prepared and antimicrobial activities against test microorganisms which are consist of Bacillus cereus CECT 131, Campylobacter jejuni NCTC 11351, Candida albicans ATCC 14053, Bacillus subtilis ATCC 6633, Enterobacter aerogenes ATCC 13048, Escherichia coli ATCC 25922, Listeria monocytogenes ATCC 7644, Salmonella typhimurium ATCC 14028, Pseudomonas aeruginosa ATCC 9027 and Staphylococcus aureus ATCC 12600 were evaluated by the disc diffusion method using $9 \mathrm{~mm}$ diameter antimicrobial activity discs (Schleicher \& Schuell, Dassel, Germany). To confirm that the antimicrobial activity was not related to acidity, neutral $\mathrm{pH}$ cell-free culture supernatants of the strain solutions were used (Rammelsberg \& Radler, 1980; Warminska-Radyko et al., 2002).

\subsubsection{Antibiotic susceptibility}

The antibiotic resistance/susceptibility profiles of strains were determined using antibiotic discs (Oxoid, Basingstoke, UK) which included ampicillin $(10 \mu \mathrm{g})$, ampicillin $(25 \mu \mathrm{g})$, bacitracin $(10 \mu \mathrm{g})$, clindamycin $(2 \mu \mathrm{g})$, clindamycin $(10 \mu \mathrm{g})$, erythromycin $(10 \mu \mathrm{g})$, erythromycin $(15 \mu \mathrm{g})$, gentamicin $(10 \mu \mathrm{g})$, gentamicin $(120 \mu \mathrm{g})$, nalidixic acid $(30 \mu)$, neomycin $(10 \mu \mathrm{g})$, novobiocin $(5 \mu \mathrm{g})$, oxacillin $(1 \mu \mathrm{g})$, penicillin (10 unit), streptomycin $(25 \mu \mathrm{g})$, streptomycin $(300 \mu \mathrm{g})$, tetracycline $(30 \mu \mathrm{g})$ and vancomycin $(30 \mu \mathrm{g})$. The tests were performed according to the criteria of the Clinical and Laboratory Standards Institute (CLSI) using Elliker Agar (Difco, Fluka, France). Lactobacillus bulgaricus and Streptococcus thermophilus strains at a level of $10^{7}$ to $10^{8}$ were inoculated onto Elliker Agar and antibiotic discs were placed in the wells and incubated under appropriate conditions. At the end of incubation, the diameters of the zones were measured and evaluated as follows: $9 \mathrm{~mm}$ : negative, $10-15 \mathrm{~mm}:+, 16-19 \mathrm{~mm}$ : ,$++ 20 \mathrm{~mm}$ and above: +++ (Wikler, 2006; Charteris et al., 1998). 


\section{Results and discussion}

In this study, nine Lactobacillus bulgaricus and nine Streptococcus thermophilus strains isolated from commercial yoghurt starter cultures were tested. Table 1 gives antimicrobial activity of Streptococcus thermophilus against some food-borne pathogens and spoilage bacteria.

As a result of this study, the Streptococcus thermophilus SY8 strain. Among all the Streptococcus thermophilus strains, the SY5 strain showed the weakest antimicrobial effect. The Streptococcus thermophilus SY8 strain exhibited antimicrobial activity against all indicator bacteria. SY5 showed the weakest antimicrobial activity with a $30 \%$ antimicrobial effect. While SY1 and SY2 strains showed an antimicrobial effect of $80 \%$, SY3, SY4, SY6, SY7 and SY10 strains showed antimicrobial effect below this rate (Table 1).

Lactobacillus bulgaricus strains LY6, LY8, LY9 and LY10 showed antimicrobial activity for all test microorganisms. Antimicrobial activity of all strains against to E. coli was shown in Figure 1. Lactobacillus bulgaricus can use to preservative purpose in the food industry, especially in the production of dairy products. The antimicrobial activity of Lactobacillus bulgaricus strains are given in Table 2. Generally, Lactobacillus bulgaricus bacteria have a greater antimicrobial effect than Streptococcus thermophilus. Four Lactobacillus bulgaricus strains (LY6, LY8, LY9 and LY10) were shown to be $100 \%$ effective and LY5 strains were shown to be $80 \%$ effective. Others (LY1, LY3 and LY4) showed the weakest antimicrobial activity with a $60 \%$ antimicrobial effect.

$\mathrm{LAB}$ and their metabolites have an important role in improving microbiological quality. Their antimicrobial activity is the most important probiotic characteristics. According to some research, strains of $L A B$ can be used in foods as preservatives and probiotics (Brkic et al., 1995; Guarner \& Malagelada, 2003; Lade et al., 2006; Sari et al., 2018).

Pishva et al. (2009) stated that the antimicrobial effect of $\mathrm{LAB}$ isolated from traditional yoghurts was determined by the spot test method against E. coli and Salmonella typhi. Most of the lactobacilli strains showed potential activity against the enteropathogenic bacteria of Salmonella and E. coli. The average zone diameter was reported to be $40.4 \mathrm{~mm}$ for E. coli. Djadouni \& Kihal (2012) examined the effect of LAB and their peptides on the spoiling bacteria (Escherichia coli, Salmonella typhimurium, Pseudomonas spp., Salmonella para-typhimurium B, Staphylococcus aureus, Clostidium spp. and Streptococcus spp.) in foods. In this study, 141 isolates were evaluated and the LBbb0141 strain

Table 1. Antimicrobial activity of Streptococcus thermophilus strains against some spoilage and pathogen microorganisms.

\begin{tabular}{|c|c|c|c|c|c|c|c|c|c|}
\hline \multirow{2}{*}{ Indicator strains } & \multicolumn{9}{|c|}{ Strains } \\
\hline & SY1 & SY2 & SY3 & SY4 & SY5 & SY6 & SY7 & SY8 & SY10 \\
\hline Bacillus cereus CECT 131 & & + & - & + & - & + & - & + & - \\
\hline Bacillus subtilis ATCC 6633 & - & + & + & + & - & - & + & + & + \\
\hline Campylobacter jejuni NCTC 11351 & + & + & + & + & - & - & + & + & + \\
\hline Candida albicans ATCC 14053 & + & + & + & - & - & + & + & + & + \\
\hline Enterobacter aerogenes ATCC 13048 & + & + & + & - & + & + & + & + & + \\
\hline Escherichia coli ATCC 25922 & + & + & + & - & - & + & + & + & - \\
\hline Listeria monocytogenes ATCC 7644 & + & + & - & + & + & + & - & + & + \\
\hline Pseudomonas aeruginosa ATCC 9027 & + & + & + & - & - & - & - & + & + \\
\hline Salmonella typhimurium ATCC 14028 & + & - & - & + & + & - & + & + & - \\
\hline Staphylococcus aureus ATCC 12600 & + & - & + & - & - & + & - & + & + \\
\hline Total percent $(\%)$ & 80 & 80 & 60 & 50 & 30 & 50 & 60 & 100 & 70 \\
\hline
\end{tabular}

+: Positive antimicrobial activity against test bacteria; -: None detected, negative antimicrobial activity against test bacteria.

Table 2. Antimicrobial activity of Lactobacillus bulgaricus strains against some spoilage and pathogen microorganisms.

\begin{tabular}{|c|c|c|c|c|c|c|c|c|c|}
\hline \multirow{2}{*}{ Indicator strains } & \multicolumn{9}{|c|}{ Strains } \\
\hline & LY1 & LY3 & LY4 & LY5 & LY6 & LY7 & LY8 & LY9 & LY10 \\
\hline Bacillus cereus CECT 131 & + & - & + & - & + & - & + & + & + \\
\hline Bacillus subtilis ATCC 6633 & - & + & + & + & + & - & + & + & + \\
\hline Campylobacter jejuni NCTC 11351 & + & + & + & + & + & + & + & + & + \\
\hline Candida albicans ATCC 14053 & - & + & + & + & + & + & + & + & + \\
\hline Enterobacter aerogenes ATCC 13048 & - & + & + & + & + & + & + & + & + \\
\hline Escherichia coli ATCC 25922 & + & - & - & + & + & + & + & + & + \\
\hline Listeria monocytogenes ATCC 7644 & + & - & - & + & + & + & + & + & + \\
\hline Pseudomonas aeruginosa ATCC 9027 & + & + & - & + & + & + & + & + & + \\
\hline Salmonella typhimurium ATCC 14028 & + & - & - & + & + & - & + & + & + \\
\hline Staphylococcus aureus ATCC 12600 & - & + & + & - & + & - & + & + & + \\
\hline Total percent $(\%)$ & 60 & 60 & 60 & 80 & 100 & 60 & 100 & 100 & 100 \\
\hline
\end{tabular}

+: Positive antimicrobial activity against test bacteria; -: None detected, negative antimicrobial activity against test bacteria. 


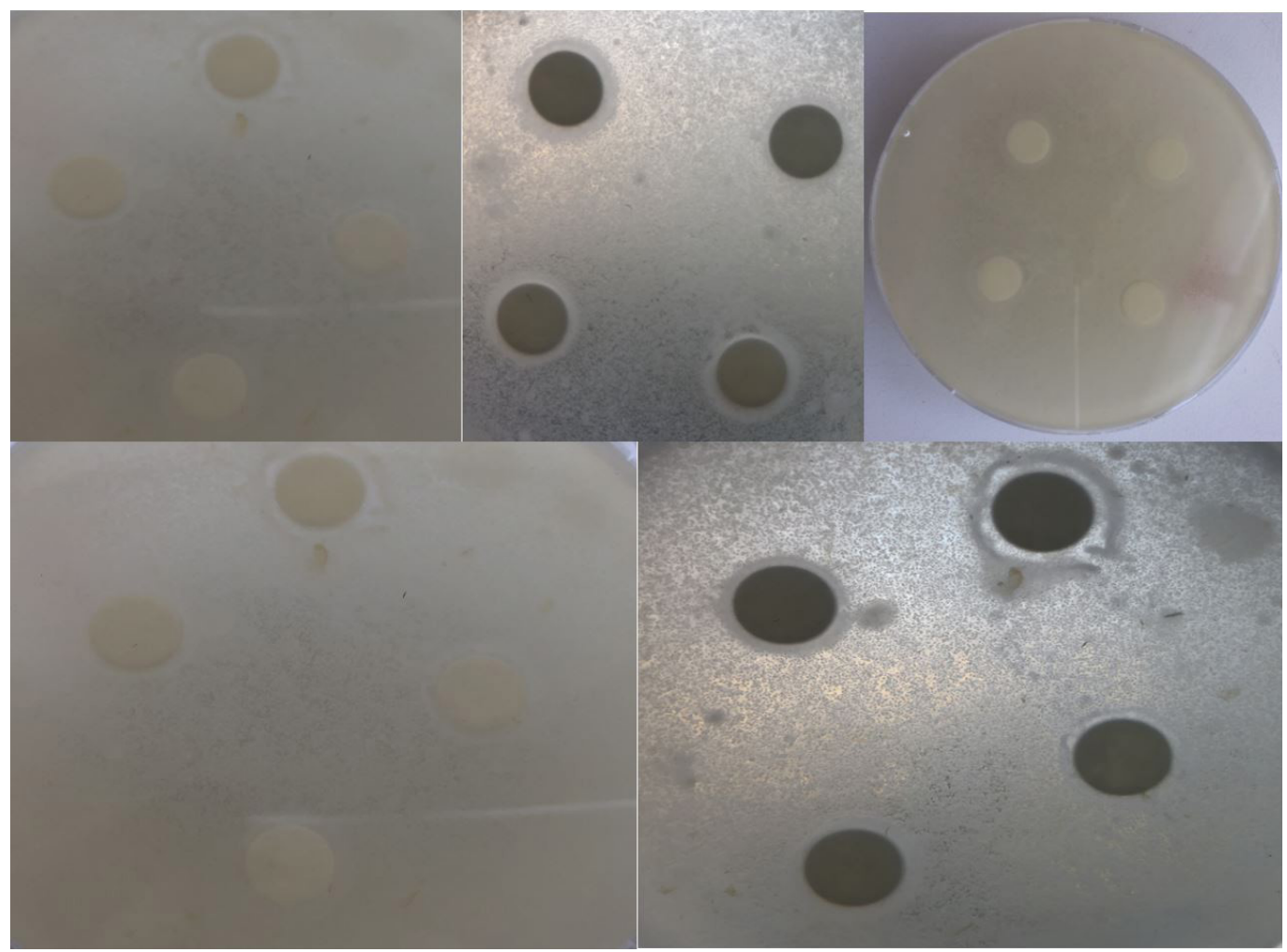

Figure 1. Antimicrobial activity of Streptococcus thermophilus and Lactobacillus bulgaricus strains against Esherichia coli.

isolated from cow milk produced the maximum inhibition zone (10 to $14 \mathrm{~mm}$ ) against all test microorganisms.

Nigam et al. (2012) researched the antibacterial activity of LAB against common enteric pathogens. This bacteria isolated from raw milk, tomato, curd and dosa batter. They reported that Lactobacillus salivarius, Lactobacillus fermentum, Lactobacillus bulgaricus and Lactobacillus acidophilus, were effective against all the selected pathogenic strains (Escherichia coli, Pseudomonas aeruginosa, Staphylococcus aureus and Bacillus cereus). Lactobacillus bulgaricus showed the highest antibacterial activity against Pseudomonas aeruginosa $(17 \pm 1.7 \mathrm{~mm})$ and lowest activity against $E$. coli $(8 \pm 1.4 \mathrm{~mm})$.

Ravindran et al. (2016) investigated the antimicrobial effects of LAB against some pathogens. Results indicated that a mixed culture of Lactobacillus bulgaricus and Streptococcus thermophilus had the highest antimicrobial activity against Staphylococcus aureus. Lactobacillus bulgaricus had the highest antimicrobial activity against Staphylococcus aureus and the lowest activity against Escherichia coli. Similar antimicrobial efficiency was seen in Lactobacillus casei.

The antibiotic resistance of Streptococcus thermophilus strains is given in Table 3 . All of the strains were resistant to ampicillin, erythromycin, streptomycin, clindamycin and vancomycin. While all Lactobacillus bulgaricus and Streptococcus thermophilus strains were resistant to oxacillin $(1 \mu \mathrm{g})$ and nalidixic acid $(30 \mu \mathrm{g})$, the highest antibiotic susceptibility was determined for antibiotics such as ampicillin $(25 \mu \mathrm{g})$, clindamycin $(10 \mu \mathrm{g})$ and erythromycin $(15 \mu \mathrm{g})$. None of the Streptococcus thermophilus strains exhibited resistance to the nalidixic acid and oxacillin. Also, few strains of
Streptococcus thermophilus exhibited resistance to novobiocin and streptomycin. While the SY6 strain did not show antibiotic resistance to nalidixic acid and oxacillin, the SY1 strain did not show antibiotic resistance to nalidixic acid, oxacillin or novobiocin.

Table 4 shows the antibiotic resistance for Lactobacillus bulgaricus strains. The LY9 strain was found to be resistant to all antibiotics. It could be said that all of the Lactobacillus bulgaricus strains have a resistant effect to ampicillin, bacitracin, cindamycin, clindamycin, erythromycin and vancomycin.

In addition, all of the Lactobacillus bulgaricus strains were found not to be resistant to the other tested antibiotics. In Figure 2 was illustrated that antibiotic susceptibility of Lactobacillus bulgaricus and Streptococcus thermophilus strains to some antibiotic discs.

Ammor et al. (2008) investigated that lactic acid bacteria isolated in Spanish cheese had tetracycline resistance. Nawaz et al. (2011) stated that 16 strains of Lactobacillus and Streptococcus thermophilus were isolated from fermented foods. All strains were identified to be susceptible to ampicillin, bacitracin and resistant to nalidixic acid, kanamycin and vancomycin (except for Lactobacillus bulgaricus, Lactobacillus acidophilus and Streptococcus thermophilus that were sensitive to vancomycin). It was reported that some strains were resistant to penicillin erythromycin, clindamycin and tetracycline. Also, it was emphasized that resistance to gentamycin, streptomycin, ciprofloxacin and chloramphenicol was dependent on species.

Ozteber (2013) detected that LAB isolated from fermented products and boza was detected against chloramphenicol (31,3\% of the isolates), erythromycin (2.4\%), ciprofloxacin (2.41\%), 
Table 3. Antibiotic suspectibility profiles of Streptococcus thermophiles strains.

\begin{tabular}{|c|c|c|c|c|c|c|c|c|c|}
\hline \multirow{2}{*}{$\begin{array}{l}\text { Antibiotics and } \\
\text { concentrations }\end{array}$} & \multicolumn{9}{|c|}{ Streptococcus thermophilus strains } \\
\hline & SY1 & SY2 & SY3 & SY4 & SY5 & SY6 & SY7 & SY8 & SY10 \\
\hline ampicillin $(10 \mu \mathrm{g})$ & +++ & +++ & - & - & - & +++ & - & + & - \\
\hline ampicillin $(25 \mu \mathrm{g})$ & +++ & +++ & +++ & +++ & +++ & +++ & +++ & ++ & +++ \\
\hline clindamycin $(2 \mu \mathrm{g})$ & +++ & +++ & + & - & +++ & +++ & +++ & ++ & - \\
\hline clindamycin $(10 \mu \mathrm{g})$ & +++ & +++ & + & +++ & +++ & +++ & +++ & +++ & +++ \\
\hline gentamicin $(10 \mu \mathrm{g})$ & + & + & - & + & - & ++ & + & + & - \\
\hline gentamicin $(120 \mu \mathrm{g})$ & ++ & +++ & - & ++ & ++ & +++ & + & ++ & +++ \\
\hline nalidixic acid $(30 \mu)$ & - & - & - & - & - & - & - & - & - \\
\hline neomycin $(10 \mu \mathrm{g})$ & + & + & - & - & + & + & - & - & + \\
\hline novobiocin $(5 \mu \mathrm{g}))$ & - & - & - & - & - & + & + & - & ++ \\
\hline tetracycline $(30 \mu \mathrm{g})$ & +++ & +++ & +++ & ++ & ++ & +++ & +++ & +++ & - \\
\hline vancomycin $(30 \mu \mathrm{g})$ & ++ & +++ & + & +++ & + & ++ & ++ & + & +++ \\
\hline
\end{tabular}

6-8 mm: negative, 9-15mm: +, 16-19mm: ++, 20mm and above: +++ .

Table 4 Antibiotic suspectibility profiles of Lactobacillus delbrueckii subsp. bulgaricus strains.

\begin{tabular}{|c|c|c|c|c|c|c|c|c|c|}
\hline \multirow{2}{*}{$\begin{array}{l}\text { Antibiotics and } \\
\text { concentrations }\end{array}$} & \multicolumn{9}{|c|}{ Lactobacillus bulgaricus strains } \\
\hline & LY1 & LY3 & LY4 & LY5 & LY6 & LY7 & LY8 & LY9 & LY10 \\
\hline ampicillin $(10 \mu \mathrm{g})$ & +++ & ++ & + & +++ & ++ & + & +++ & ++ & + \\
\hline ampicillin $(25 \mu \mathrm{g})$ & +++ & +++ & +++ & +++ & +++ & ++ & +++ & +++ & ++ \\
\hline bacitracin $(10 \mu \mathrm{g})$ & + & + & + & ++ & + & + & + & ++ & + \\
\hline clindamycin $(2 \mu \mathrm{g})$ & ++ & ++ & ++ & ++ & ++ & + & +++ & +++ & + \\
\hline clindamycin $(10 \mu \mathrm{g})$ & +++ & +++ & +++ & +++ & +++ & ++ & +++ & +++ & ++ \\
\hline erythromycin $(10 \mu \mathrm{g})$ & +++ & ++ & ++ & +++ & +++ & + & +++ & +++ & ++ \\
\hline erythromycin $(15 \mu \mathrm{g})$ & +++ & +++ & ++ & +++ & +++ & + & +++ & +++ & ++ \\
\hline gentamicin $(10 \mu \mathrm{g})$ & + & - & + & + & + & - & + & + & - \\
\hline gentamicin $(120 \mu \mathrm{g})$ & + & + & + & ++ & ++ & + & ++ & +++ & - \\
\hline nalidixic acid $(30 \mu)$ & - & - & - & - & - & - & - & - & - \\
\hline neomycin $(10 \mu \mathrm{g})$ & + & + & - & + & + & +++ & + & + & - \\
\hline novobiocin $(5 \mu \mathrm{g})$ & + & - & + & - & + & - & ++ & +++ & + \\
\hline oxacillin $(1 \mu \mathrm{g})$ & - & - & - & - & - & - & - & - & - \\
\hline penicillin (10unit) & + & + & + & ++ & + & - & + & +++ & - \\
\hline streptomycin $(25 \mu \mathrm{g})$ & - & + & - & + & - & - & + & + & - \\
\hline streptomycin $(300 \mu \mathrm{g})$ & + & ++ & + & + & + & - & + & + & - \\
\hline tetracycline $(30 \mu \mathrm{g})$ & +++ & +++ & +++ & +++ & +++ & + & - & +++ & +++ \\
\hline vancomycin $(30 \mu \mathrm{g})$ & + & + & + & + & + & + & + & +++ & + \\
\hline
\end{tabular}

6-8mm: negative, 9-15mm: +, 16-19mm: ++, $20 \mathrm{~mm}$ and above: +++ .

tetracycline (30,1\%), vancomycin (73.5\%, intrinsic resistance). Federici et al. (2014) examined the antibiotic resistance characteristics of LAB strains from salami produced in the Marche region of Italy. While Lactobacillus strains showed a high resistance to aminoglycosides such as streptomycin and gentamicin, Streptococcus strains were resistant to gentamicin and chloramphenicol.

Singh et al. (2016) isolated 110 Lactobacillus from food samples in the city of Allahabad in India. It was reported that approximately $47.4 \%$ of the isolated LAB were resistant to ampicillin concentrations of $5 \mathrm{mg} / \mathrm{ml}$ and to streptomycin concentrations of $2.5 \mathrm{mg} / \mathrm{ml}$. In this study, approximately $44.2 \%$ of the isolates were found to be sensitive to $10 \mathrm{mg} / \mathrm{ml}$ ampicillin and streptomycin. Celik et al. (2016) investigated the antibiotic susceptibility of LAB isolated from homemade and some commercial yoghurts. In their study, the disc diffusion method was applied to determine antibiotic susceptibility and resistance of 19 lactobacilli and 19 Streptococcus strains. Ten different antibiotic discs were used and inhibition zone diameters were measured after an incubation period. Lactobacillus strains were $100 \%$ resistant 


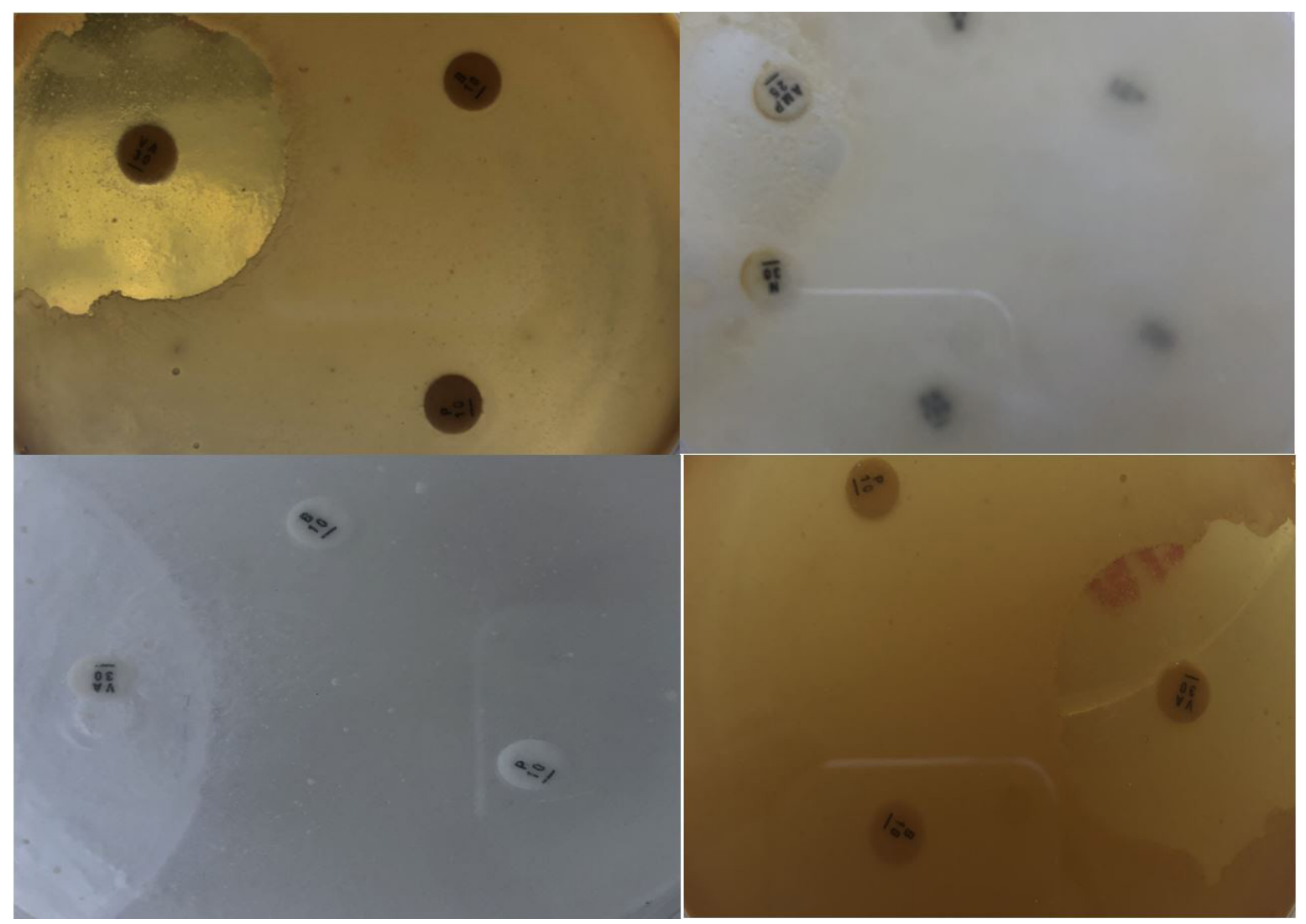

Figure 2. Antibiotic sensivity of Lactobacillus bulgaricus and Streptococcus thermophilus strains against some antibiotic.

to trimethoprim-sulfamethoxazole and ofloxacin and $52.6 \%$ against gentamicin, whereas Streptococcus strains were $84.21 \%$ resistant to trimethoprim-sulfamethoxazole, $31.57 \%$ resistant to cefotaxime and $26.35 \%$ resistant to gentamicin. It was reported that Lactobacillus strains were more resistant to gentamicin than Streptococcus strains. Generally, lactobacilli species are known to be resistant to antibiotics such as tetracycline, vancomycin and trimethoprim. In contrast, LAB are known to be highly susceptible to antibiotics such as penicillin, chloramphenicol, ampicillin, erythrosine and clindamycin (Meral \& Korukluoglu, 2014).

Naturally produced antimicrobial agents that have no negative effects on human health are an important research topic. Many strains of LAB have these features at different levels. The resistance and antimicrobial activity capabilities of LAB, which are the main agents of yogurt production, are very important for dairy industry. Strains with high antibiotic resistance and antimicrobial activity are preferred when evaluated in terms of industry, as well as providing textural and rheological characteristics. For this reason, antibiotic resistance and antimicrobial activity capabilities of LAB have been the subject of research for many studies (Maragkoudakis et al., 2006; Charlier et al., 2008; Khay et al., 2011; Olaniyi et al., 2019).

\section{Conclusions}

The antimicrobial effect of LAB can be caused by many factors, such as the production of lactic acid, aldehydes, bacteriocin and other compounds. Also, the reduction of $\mathrm{pH}$ and acetic acid, hydrogen peroxide. In our study, the 1 Streptococcus thermophilus and 4 Lactobacillus bulgaricus strains were reported to have a $100 \%$ antimicrobial effect against food-borne pathogens and spoilage bacteria. Among all Streptococcus thermophilus strains only the SY4 strains did not show an antimicrobial effect against Enterobacter aerogenes, whereas LY1 strains did not show any antimicrobial effect among the Lactobacillus bulgaricus strains. In addition, all Lactobacillus bulgaricus strains were reported to have antimicrobial activity against Campylobacter jejuni NCTC 11351. In conclusion, the results obtained from this study demonstrated the remarkable antimicrobial attributes of the Streptococcus thermophilus and Lactobacillus bulgaricus strains. This remarkable antimicrobial effect is also supported by previous studies.

And also, it is reported that LAB, which are accepted as GRAS (Generally Recognized As Safe), have antibiotic resistance. This study showed that all Streptococcus thermophilus strains showed resistance to clindamycin $(10 \mu \mathrm{g})$, erythromycin $(10 \mu \mathrm{g})$ and vancomycin $(30 \mu \mathrm{g})$. When the status of lactobacilli strains against pathogens is evaluated, all Lactobacillus bulgaricus strains were resistant to ampicillin $(10 \mu \mathrm{g})$, ampicillin $(30 \mu \mathrm{g})$, bacitracin $(10 \mu \mathrm{g})$, cindamycin $(2 \mu \mathrm{g})$, clindamycin $(10 \mu \mathrm{g})$, erythromycin $(10 \mu \mathrm{g})$, erythromycin $(10 \mu \mathrm{g})$ and vancomycin $(30 \mu \mathrm{g})$. These values indicated that Lactobacillus bulgaricus strains have a higher antibiotic resistance than Streptococcus thermophilus. It could be said that antimicrobial properties and the resistance of antibiotics to starter cultures used in commercial yoghurts 
are very important for production and nutrition. It is very important for starter cultures used in commercial yoghurt to have antimicrobial properties and to resist antibiotics. The starter cultures used in the production of yoghurts sold in the market need to have these properties.

\section{References}

Ammor, M. S., Florez, A. B., Van Hoek, H. A., de Los Reyes-Gavilan, G. C., Aarts, H. J., Margolles, A., \& Mayo, B. (2008). Molecular characterization of Intrinsic and acquired antibiotic resistance in Lactic acid bacteria and Bifidobacteria. Journal of Molecular Microbiology and Biotechnology, 14(1-3), 6-15. http://dx.doi. org/10.1159/000106077. PMid:17957105.

Bintsis, T. (2018). Lactic acid bacteria as starter cultures: An update in their metabolism and genetics. AIMS Microbiology, 4(4), 665-684. http://dx.doi.org/10.3934/microbiol.2018.4.665. PMid:31294241.

Brkic, B., Suskovic, J., Matosic, S., \& Gjuracic, K. (1995). Ability of chosen lactic acid bacteria to produce antibacterial substances. Prehrambeno-Tehnology and Biotechnology Reviews, 33, 145-150.

Caplice, E., \& Fitzgerald, G. F. (1999). Food fermentation: role of microorganisms in food production and preservation. International Journal of Food Microbiology, 50(1-2), 131-149. http://dx.doi. org/10.1016/S0168-1605(99)00082-3. PMid:10488849.

Carr, F. J., Chill, D., \& Maida, N. (2002). The lactic acid bacteria: A literature survey. Critical Reviews in Microbiology, 28(4), 281-370. http://dx.doi.org/10.1080/1040-840291046759. PMid:12546196.

Celik, H., Durak, Y., \& Uysal, A. (2016). Bazı ticari ve ev yapımı yoğurtlardan izole edilen laktik asit bakterilerinin antibiyotik duyarlılıkları. Fen Fakültesi Fen Dergisi, 42(2), 149-160.

Charlier, C., Even, S., Gautier, M., \& Le Loir, Y. (2008). Acidification is not involved in the early inhibition of Staphylococcus aureus growth by Lactococcus lactis in milk. International Dairy Journal, 18(2), 197-203. http://dx.doi.org/10.1016/j.idairyj.2007.03.015.

Charteris, W. P., Morelli, L., Kelly, P. M., \& Collins, J. K. (1998). Development of an agar overlay disc diffusion method for the antibiotic susceptibility testing of potentially probiotic Lactobacillus and Bifidobacterium species. Egyptian Journal of Dairy Science, 26(2). http://dx.doi.org/10.4315/0362-028X-61.12.1636. PMid:9874341.

Chetachukwu, A. S., Thongraung, C., \& Yupanqui, C. T. (2019). Development of reduced-fat coconut yoghurt: physicochemical, rheological, microstructural and sensory properties. International Journal of Dairy Technology, 72(4), 524-535. http://dx.doi. org/10.1111/1471-0307.12600.

Coskun, F., \& Karabulut Dirican, L. (2019). Effects of pine honey on the physicochemical, microbiological and sensory properties of probiotic yoghurt. Food Science and Technology, 39(Suppl. 2), 616625. http://dx.doi.org/10.1590/fst.24818.

Crowley, S., Mahony, J., \& van Sinderen, D. (2013). Current perspectives on antifungal lactic acid bacteria as natural bio-preservatives. Trends in Food Science \& Technology, 33(2), 93-109. http://dx.doi. org/10.1016/j.tifs.2013.07.004.

Cruz, A. G., Cadena, R. S., Walter, E. H., Mortazavian, A. M., Granato, D., Faria, J. A., \& Bolini, H. (2010). Sensory analysis: relevance for prebiotic, probiotic, and synbiotic product development. Comprehensive Reviews in Food Science and Food Safety, 9(4), 358-373. http://dx.doi. org/10.1111/j.1541-4337.2010.00115.x.

De Man, J. C., Rogosa, M., \& Sharpe, M. (1960). A medium for the cultivation of Lactobacilli. Journal of Applied Microbiology, 23(1), 130-135. http://dx.doi.org/10.1111/j.1365-2672.1960.tb00188.x.
Djadouni, F., \& Kihal, M. (2012). Antimicrobial activity of lactic acid bacteria and the spectrum of their biopeptides against spoiling germs in foods. Brazilian Archives of Biology and Technology, 55(3), 435-443. http://dx.doi.org/10.1590/S1516-89132012000300015.

Federici, S., Ciarrocchi, F., Campana, R., Ciandrini, E., Blasi, G., \& Baffone, W. (2014). Identification and functional traits of lactic acid bacteria isolated from Ciauscolo salami produced in Central Italy. Meat Science, 98(4), 575-584. http://dx.doi.org/10.1016/j. meatsci.2014.05.019. PMid:25089780.

Granato, D., Branco, G. F., Cruz, A. G., Faria, J. A. F., \& Shah, N. P. (2010). Probiotic dairy products as functional foods. Comprehensive Reviews in Food Science and Food Safety, 9(5), 455-470. http://dx.doi. org/10.1111/j.1541-4337.2010.00120.x.

Guarner, F., \& Malagelada, J. R. (2003). Gut flora in health and disease. Lancet, 361(9356), 512-519. http://dx.doi.org/10.1016/S01406736(03)12489-0. PMid:12583961.

Hill, C., \& Ross, R. P. (1998). Starter cultures for the dairy industry. In S. Roller and S. Harlander (Eds.), Genetic modification in the food industry. London: Blackie Academic and Professional. http://dx.doi. org/10.1007/978-1-4615-5815-6_9.

Kandler, O. (1983). Carbohydrate-metabolism in lactic-acid bacteria. Antonie van Leeuwenhoek Journal of Microbiology, 49(3), 209-224. http://dx.doi.org/10.1007/BF00399499. PMid:6354079.

Khay, E., Idaomar, M., Castro, L. M. P., Bernárdez, P. F., Senhaji, N. S., \& Abrini, J. (2011). Antimicrobial activities of the bacteriocin-like substances produced by lactic acid bacteria isolated from Moroccan dromedary milk. African Journal of Biotechnology, 10(51), 1044710455. http://dx.doi.org/10.5897/AJB11.1328.

Lade, H. S., Chitanand, M. P., Gyananath, G., \& Kadam, T. A. (2006). Studies of some properties of bacteriocins produced by Lactobacillus species isolated from agro-based waste. The Internet Journal of Microbiology, 2(1), 1-5.

Liu, D. (2018). Effect of Fuzhuan brick-tea addition on the quality and antioxidant activity of skimmed set-type yoghurt. International Journal of Dairy Technology, 71(Suppl. 1), 22-33. http://dx.doi. org/10.1111/1471-0307.12395.

Liu, E., Hao, P., Konno, T., Yu, Y., Oda, M., Zheng, H., \& Ji, Z. (2012). Amino acid biosynthesis and proteolysis in Lactobacillus bulgaricus revisited: A genomic comparison. Comprehensive Molecular Bioscience, 2(03), 61-77. http://dx.doi.org/10.4236/cmb.2012.23006.

Maragkoudakis, P. A., Zoumpopoulou, G., Miaris, C., Kalantzopoulos, G., Pot, B., \& Tsakalidou, E. (2006). Probiotic potential of Lactobacillus strains isolated from dairy products. International Dairy Journal, 16(3), 189-199. http://dx.doi.org/10.1016/j.idairyj.2005.02.009.

Mathur, S., \& Singh, R. (2005). Antibiotic resistance in food lactic acid bacteria- A Review. International Journal of Food Microbiology, 105(3), 281-295. http://dx.doi.org/10.1016/j.ijfoodmicro.2005.03.008. PMid:16289406.

Meral, H., \& Korukluoglu, M. (2014). Laktik asit bakterilerinin antibiyotik direnç mekanizmaları. UÜ Ziraat Fakültesi Dergisi, 28(2), 71-82.

Nawaz, M., Wang, J., Zhou, A., Ma, C., Wu, X., Moore, J. E., Cherie Millar, B., \& Xu, J. (2011). Characterization and transfer of antibiotic resistance in lactic acid bacteria from fermented food products. Current Microbiology, 62(3), 1081-1089. http://dx.doi.org/10.1007/ s00284-010-9856-2. PMid:21212956.

Nigam, A., Kumar, A., Madhusudan, H. V., \& Bhola, N. (2012). In-vitro screening of antibacterial activity of lactic acid bacteria against common enteric pathogens. Journal of Biomedical Science, 1(42), 1-6. http://dx.doi.org/10.3823/1010. 
Olaniyi, O. I., Adeniran, H. A., \& Abiose, S. H. (2019). Antimicrobial characteristics of lactic acid bacteria in African yam bean-based drink. International Food Research Journal, 26(6), 1733-1740.

Ozteber, M. (2013). Fermente süt ürünlerinden izole edilen laktik asit bakterilerinin antibiyotik dirençliliklerinin fenotipik ve genotipik yöntemlerle belirlenmesi. Aydın: Yüksek Lisans Tezi, Adnan Menderes Üniversitesi, Fen Bilimleri Enstitüsü.

Pishva, E., Hassannia, N., Fazeli, M. R., Havaee, A., Jamalifar, H., Hossein, M. P., Shojaee, H., \& Akbari, M. (2009). Antibacterial effect of authochlorous Lactobacillus strains isolated from traditional yogurts. Pakistan Journal of Nutrition, 8(8), 1132-1137. http://dx.doi. org/10.3923/pjn.2009.1132.1137.

Rammelsberg, M., \& Radler, F. (1980). Antibacterial polypeptides of Lactobacillus species. The Journal of Applied Bacteriology, 69(2), 177-184. http://dx.doi.org/10.1111/j.1365-2672.1990.tb01507.x.

Ranadheera, C. S., Evans, C. A., Baines, S. K., Balthazar, C. F., Cruz, A. G., Esmerino, E. A., Freitas, M. Q., Pimentel, T. C., Wittwer, A. E., Naumovski, N., Graça, J. S., Sant'Ana, A. S., Ajlouni, S., \& Vasiljevic, T. (2019). Probiotics in goat milk products: Delivery capacity and ability to improve sensory attributes. Comprehensive Reviews in Food Science and Food Safety, 18(4), 867-882. http:// dx.doi.org/10.1111/1541-4337.12447.

Ranasinghe, J. G. S., \& Perera, W. T. R. (2016). Prevalence of Lactobacillus bulgaricus and Streptococcus thermophilus stability in commercially available yogurts in Sri lanka. Asian Journal of Medical Sciences, 7(5), 97-101. http://dx.doi.org/10.3126/ajms.v7i5.14326.

Ravindran, L., Manjunath, N., Darshan, R. P., \& Manuel, S. (2016). In vitro study analysis of antimicrobial properties of lactic acid bacteria against pathogens. Journal of Biotechnology Innovation, 5(2), 262-269.
Ribeiro, A. S., Silva, M. N., Tagliapietra, B. L., Brum, B. S. Jr, Ugalde, M. L., \& Richards, N. S. P. S. (2019). Development of symbiotic yoghurt and biological evaluation (New Zealand White Rabbits) of its functional properties. Food Science and Technology, 39(Suppl. 2), 418-425. http://dx.doi.org/10.1590/fst.20618.

Sari, M., Suryonto, D., \& Yurnaliza. (2018). Antimicrobial activity of lactic acid bacteria isolated from bekasam against Staphylococcus aureus ATCC 25923, Escherichia coli ATCC 25922, and salmonella sp. Earth and Environmental Science, 130, 1-8. http://dx.doi. org/10.1088/1755-1315/130/1/012011

Singh, P., Saini, P., Sachan, S., \& Dubey, S. (2016). Characterization, antimicrobial activity and antibiotic susceptibility of lactic acid bacteria isolated from food samples. International Journal of Current Microbiology and Applied Sciences, 5(7), 901-911. http://dx.doi. org/10.20546/ijcmas.2016.507.102.

Suskovic, J., Blazenka, K., Beganovic, Z., Pavunc, A. L., Habjanic, K., \& Matosic, S. (2010). Antimicrobial activity - The most important property of probiotic and starter lactic acid bacteria. Food Technology and Biotechnology, 48(3), 296-307.

Terzaghi, B. E., \& Sandine, W. E. (1975). Improved medium for lactic streptococci and their bacteriophages. Applied Microbiology, 29(6), 807-813. http://dx.doi.org/10.1128/AEM.29.6.807-813.1975. PMid:16350018.

Warminska-Radyko, I., Laniewska-Moroz, L., \& Babuchowski, A. (2002). Possibilities for stimulation of Bifidobacterium growth by propionibacteria. Le Lait, 82(1), 113-121. http://dx.doi.org/10.1051/ lait:2001010.

Wikler, M. A. (2006). Performance standards for antimicrobial susceptibility testing: Sixteenth informational supplement. Wayne, PA: Clinical and Laboratory Standards Institute. 